\title{
Overview on the Distribution System of Mineral Energy Ownership in China
}

\author{
Weijia Zhang \\ China University of Political Science and Law, Beijing, China \\ Email: sirlituo@126.com \\ Received May 2014
}

\begin{abstract}
This paper is a preliminary exploration on the attribution system of mineral energy ownership of China. In this article, mineral energy is broken down into two categories, namely, the energy minerals and the products of energy minerals. Subsequently, this paper further elaborates and makes a pectination to the energy ownership system according to the mode of acquisition of the two types of mineral energy in China.
\end{abstract}

\section{Keywords}

Energy Ownership, Mineral Energy, Energy Minerals, Products of Energy Minerals

\section{Introduction}

"Energy Resources” is a rather broad concept. In view of this concept, scholars with various backgrounds have made different interpretations. Some deem “energy resources” as a sort of "capacity” [1], others consider it "substance or movement of substance” [2]. In recent years, "energy resources” is mostly viewed as a type of "resources" in China's academic circles, which means that "energy resources is all kinds of resources that is able to produce useful energy through the conversion processes directly or indirectly, including primary energy sources like coal, crude oil, ... and secondary energy sources like electricity, heat, refined oil” [3]. According to this definition, which is also favored by many other Chinese experts [4], energy resources include not just the natural resources, but also the energy products, namely, secondary energy sources. In term of mineral energy, it can be divided into energy minerals (hereinafter referred as "EM") as the primary energy resources and the products of energy minerals (hereinafter referred as "PEM”) as the secondary energy resources.

According to the Appendix Catalogue of the Mineral Resources of "Rules for Implementation of the Mineral Resources Law of the PRC” (hereinafter referred to as the "Rules”), EM includes coal, petroleum, natural gas, etc [5]. In China, it is exclusively owned by the State.

PEM are energy converted or processed from energy resources that can be utilized directly by human beings. For example, the mined and refined oil, petroleum coke, head coal, run coal, etc Considering PEM no longer falls into the sphere of concerns regarding sovereign issues as EM does, therefore, the subject of ownership are not limited to the state anymore. And the modes of acquisition are far more diverse. 


\section{Ownership of EM Belongs to the State}

In China, EM is always state-owned because of its important position in national economy. Professor Lee Guoping referred such layout as "unshakable” [6]. However, since the sovereign state is not capable of participating in the civil and commercial legal relationship, the subjects to exercise the ownership of EM is not the State anymore.

\subsection{Subjects to Exercise the Ownership of EM}

Acquisition of the ownership of EM is initial. In other words, the State's absolute ownership is based on the requirements of national sovereignty [7]. According to China's Constitution, Property Law, Mineral Resources Law, and Coal Industry Law, the mineral resources are "owned by the state, that is, by the whole people” and it "shall not change with the alteration of ownership of the land or right to use the land which the mineral resources are attached to" [8]. Thus, there is simply no market for EM resources. The subject of the ownership is restricted to the state only. In practice, such right is exercised under the representative of the State Council. In addition, sometimes the State Council will confer it to the local government and related departments. According to Dr. Wu yin, most property and control of the mining enterprises are decentralized to the provincial government, yet the ones that are essential to national economy remains under the direct control of central government [9]. Therefore, in form, the State Council, authorized local governments and relevant departments can exercise the state ownership on behalf of the State, but in the essence the true owner of energy minerals still remains the State.

\subsection{Legal Nature of the State's Ownership of EM}

It's worth noting that the state's ownership is different from the ownership in civil law, which is commonly assumed. Some Chinese scholars consider the state's ownership as a constitutional right [10]. As professor Gao Fuping points out: "State's ownership actually is rather a systematic measure to guarantee all the people of the equity to enjoying ownership or its interests than a form of ownership in civil law sense. It is a strategy to ensure the rational utilization of important social property and balanced, sustainable development. The significance of the measure lies in its system value" [11]. In this sense, "the state is but the tool and agent for the people to realize their goals" [12]. In my humble opinion, this means the only legitimate ground for the State to own all mineral energy is to make sure that the social resources will be fully used for the interests of the whole society, and that is the limitation that the State's ownership of EM has to endure.

\section{Obtain the Ownership of PEM}

Apart from EM, another important part of mineral energy is PEM which is created from the mining, processing and conversion of EM. Compared to minerals, mineral products contain higher economic value because the human labor is added. In addition, since the sovereignty concerns no longer exist at this stage, any enterprise or individual can become the owner of energy. In this regard, the energy finally achieves its terminal utility by the allocation of the supply-demand relation through the PEM transactions.

According to the different channels of acquisition, the source of PEM can be divided into two types: one is the market, another is compulsory collection, which can only be exercised by the State "in the public interest" [13]. Since the latter approach is not the normal and common practice, it will not be further elaborated in this article.

As to obtain the ownership of PEM in market, it comprises two methodologies: first is to create their own PEM from scratch by exercising mineral rights, and the second is to take possessions of PEM from others through commercial contracts.

\subsection{Original Acquisition of PEM}

Original acquisition of PEM means to create PEM from EM, which is based on the performance of mineral rights. In accordance with the Rules, the mining rights "means the right to exploit the mineral resources and to own the mineral products within the scope provided by the mining license" [14]. Further, the mining rights involve the right of "selling the mineral products by themselves" [15]. It can be referred that concessionaires [16] 
indeed own the PEM mined by themselves. In comparison, the ownership of the exploration licensees towards PEM is subject to more restrictions. The only mineral products they can sell by themselves are those "recycled during the exploration operation in accordance with the project design that has been approved". But as to "minerals which shall be sold to the designated units only as prescribed by the State Council”, neither the exploration licensees nor the concessionaires has the freedom to sell at their own wishes [17]. Ownership of the said minerals are limited to certain extend.

In the course of exercising the mineral rights, by exploration and exploitation, along with the gradual disappearance of EM, PEM is produced. Accordingly, the state's ownership of EM is replaced by units' or individuals' ownership of PEM, which is the best way for EM to achieve its own economic energy and mineral interests. In the terminal phase of this process, energy is no longer public goods but a private one, which is available for sale and other forms of transference. As can be seen, the mode of original acquisition of PEM has close connection with mineral rights. Actually, knowing the acquisition pattern and market structure of mineral rights is particularly important in understanding how PEM is produced. With the increasing demand for mineral resources, China’s mineral rights market is booming. Until 2010, China has built 15 provincial mineral rights trading platform, 37 reserves accrediting bodies and 93 mining rights assessment agency.

\subsubsection{Subject of Mineral Rights Market}

According to "Mineral Resources Law", the state-owned mining enterprises, collectively-owned mining enterprises and privately-owned mining undertakings are all possible concessionaires. However, the sphere of mining and exploration varies. As professor Zhang Wenju points out, "In China, the legal status of the subjects of mineral rights are not equitable. The State-owned mining enterprises are given extra preferential protections and they are dominant in almost all core, valuable or important mineral mining industry" [18]. In addition, China also allows foreign investment to obtain mining rights. Promulgated as early as 1982, the "Regulations of the People's Republic of China on The Exploitation of Off-shore Petroleum Resources in Cooperation with Foreign Enterprises" and "Regulations of the People's Republic of China on Exploitation of On-shore Petroleum Resources in Cooperation with Foreign Enterprises" in 1993 both permits foreign companies to cooperate with the Chinese on the offshore and onshore oil exploitation. Even so, as for some important fields, however, which is essential to national economy, foreign investment are still somehow restricted, especially the foreign-owned enterprises. For example, wholly foreign-owned enterprises are still banned from trading of oil, natural gas risk exploration and development, and exploration, development of coalbed methane.

Because mineral resources are usually concealed underground with pockety distribution and the mining process is rather complex and sometimes dangerous, therefore, the requirements of being a subject of mineral rights are generally higher than those of the general civil subject [19]. Requirements of an exploration licensee are specified in the "Regulations on Administration of Geological Exploration Qualifications", where the exploration for EM is deemed as "comprehensive geological exploration". The requirements for being a legitimate concessionaire are regulated in Art.11, Art. 13 and Art. 14 of the Rules.

\subsubsection{Obtain the Mineral Rights}

The entire mineral rights market can be divided into the primary and secondary markets according to the different origin they derive from.

In the primary market, the State or the departments authorized to exercise ownership of the mineral energy on behalf of the State would sell the mineral rights to qualified units or individuals in exchange of appropriate fee so that the power of EM ownership is realized. According to "Administration of Granting and Assigning Mining Industry Rights Tentative Provisions", "Administration of Invitation for Bids Auction and Listing of Exploration Rights and Mining Righs Measures (Trial Implementation)" and "Notice of the Ministry of State Land and Resources about Further Regulating the Management of Transfer of Mining Rights", the modes of transfering mining and exploration rights inlude applications, agreements, tender, auction and listing, etc.

In the secondary market, the way to obtain mineral rights is by assignment. Permission of transferring mineral rights by assignment and build the secondary market is an important part of the 1996 amendment to "Mineral Resources Law". However, taking into account the peculiarities of the state's mineral resources, the transfer of mineral rights is still under rather strict regulations. Since 1998, the State Council and the Ministry of Land and Resources (MLR) has successively promulgated the "Regulation for Reigstering to Explore for Mineral Resources Using the Block System”, the "Administrative Measures for the Registration of Mineral Resources Ex- 
ploitation" and so forth to make sure nothing goes wrong in the transference [20]. Promulgations of these regulations work together to build a more perfect and sound regulatory system for the secondary mineral rights market. Judging from these regulations, China has adopted restrictionism approach to assign mineral rights, which means the legitimate ways to assign mineral rights are restricted to sale, contributed as capital at certain value and restructuring (listing), etc. [21].

\subsection{Indirect Acquisition of PEM}

Indirect acquisition of PEM means to obtain PEM from the prior holders on the basis of mutual agreement. By the different source of PEM, it can be divided into acquisition from international trade and from domestic trade.

In 2012, China's total value of imports of Mineral Fuels, Lubricants and Related Materials has reached 313.084 billion U.S. dollars, which is three times as much as in 2007. In addition, as the data of China Customs Statistics from 2001 to 2008 suggests, China's external dependence rate on foreign oil has reached 50.9\% in 2008, which indicates that obtaining PEM through international trading has become the mainstay of acquiring energy ownership. However, considering the essential status of PEM in national economy, normally countries would adopt the policy of diversification on energy imports to ensure the security of energy supply. Therefore, in order to import energy minerals, non-state-owned enterprises often need to comply with certain conditions and procedures required by relevant department [22]. In addition, the import or export of PEM also needs to stand to the "Foreign Trade Law" and the "People's Republic of Regulation of the PRC on the Administration of the Import and Export of Goods".

National PEM market is the domestic source of obtaining its ownership. The PEM trading market is mainly divided into two categories: one is refined oil markets, the other the coal markets. But in fact, never a fully competitive refined oil market has ever been successfully established in China. From the perspective of oil marketing, more than $70 \%$ of the market share is occupied by two state-owned enterprises, Petro China and SINOPEC. Although the number of social gas stations are also quite a few, their oil are still imported from the two monopoly enterprises. According to some experts, in the term of the whole industrial chain of refined oil, the two groups have indeed formed de facto monopoly. In contrast, despite the problems like unprofessional services and disqualification still exist, the national coal trading system which is basically founded upon the state's coal trading centre and supplemented by the regional coal market has already been established [23]. Through these two types of energy minerals trading markets, increasing number of qualified units and individuals has become the owner of energy.

\section{References}

[1] Encyclopedia Britannica (2013) Energy, in Physics, the Capacity for Doing Work. http://www.britannica.com/EBchecked/topic/187171/energy

[2] Xiao, Q.G. and Xiao G.X. (1996) Energy Law. Law Press, p. 21.

Gong, X. Q. (2008) On the Reform of Energy Law under the Background of Climate Change. China Democracy and Legal System Publishing House, p. 9.

[3] Lv, Z.Y. (2008) On Energy Law. China Electric Power Press, p. 1.

[4] Sun, H.L. (2000) Encyclopedia of China Resources Science. Encyclopedia of China Publishing House, p. 548. Liu, H. (2006) Thinkings Regarding China’s Energy Law Legislation. International Petroleum Economics. [Quoted from Huang, Z.Z., Zhao, Q.Y. and Tan B.P. (2009) Studies of China Energy Law. Law Press, p. 4]

[5] According to Appendix Catalogue of the Mineral Resources of the Rules (hereinafter referred as "Rules”), energy minerals include coal, coal-related gas, stone coal, oil shale, petroleum, natural gas, oil sand, natural bitumen, uranium, thorium, geothermal resources.

[6] Lee, G.P. and Zhou, C. (2012) Definition of Property Rights of Mineral Resources in China: A Literature Overview. Economic Issues Exploration, 6, 145-150.

[7] Mei, X.Y. (2007) Property Law Ownership. China Legal Publishing House, p. 110. (This also determined the sphere the State owns the energy, the energy that concerns sovereignty)

[8] PRC Constitution, Art. 9; Property Law, Art. 45, 46, 47, 48.

Mineral Resources Law, Art. 3.

Coal Industry Law, Art. 3

[9] Wu, Y. (2009) Researching on the Reform of Chinese Mineral Resources Property Rights Institution: From the Angle 
of Central and Local Government Decentralization. Ph.D. Thesis, Southwestern University of Finance and Economics, p. 72.

[10] Cui, J.Y., Peng C.X., Dai M.Y., et al. (2012) Study on Natural Resources Property Legal System. Law Press China, p. 37.

[11] Gao, F.P. (2000) Legal Connotation of Public and Private Ownership. Tsinghua Law Review, 3rd Series, Tsinghua University Press.

[12] Wang, J. (2003) The Legal Myth of the State Ownership: Analyses on the Corporatization of China's State-owned Enterprises. Ph.D. Thesis, China’s University of Political Science and Law, p. 17.

[13] PRC Constitution, Art. 13.

[14] Rules, Art. 6.

[15] Id, Art. 30.

[16] MacBride Jr., W. L. and Wang B. (2001) Chinese Mining Law Overview. Energy and Natural Resources Law, 19, p. 220. [According to the Rules, Art. 6, the mining license holders of a mining right are termed "concessionaires" and the exploration license holders exploration licensee]

[17] Mineral Resources Law, Art. 34.

Rules, Art. 16, 30.

[18] Zhang, W.J. (2004) Properties and Market System of Mining Rights. Chinese Economics Geology and Mineral Resources, 10, 15-25.

[19] Fang, S.K. (2013) Research on the Legal System of Exploration and Mining Rights. China Legal Publishing House, p. 31.

[20] Other Regulations include "Measures for the Administration of Transfer of Mineral Exploration Right and Mining Right”, “Administration of Granting and Assigning Mining Industry Rights Tentative Provisions” and "Trading Rules for Mineral Mining and Exploration Rights (Trial Implementation)”.

[21] Administration of Granting and Assigning Mining Industry Rights Tentative Provisions, Art. 6.

[22] For example, the Announcement 2013 No.72 of MOFCOM on Total Amount, Application Qualifications and Application Procedures Concerning Brut Oil Import Quota for Non SOEs in 2014.

[23] Duan, X.M. (2012) Study of Shanxi Coal Trading Center Operations Model. Master's Thesis, Northwestern University, p. 20. 